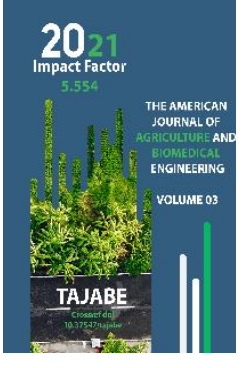

Journal Website: https://theamericanjou rnals.com/index.php/ta jabe

Copyright: Original content from this work may be used under the terms of the creative commons attributes 4.0 licence.

\section{The Importance Of Planting And Processing Of Medium- Field Cotton Varieties Between Cotton Rows In Fergana Region}

\author{
Ubaydullayev Madamin Mo'minovich \\ Candidate Of Agricultural Sciences, Senior Lecturer, Department Of "Technology Of Storage \\ And Processing Of Agricultural Products", Fergana Polytechnic Institute, Fergana, Uzbekistan \\ Ne'matova Feruzaxon Jamolxon Qizi \\ Assistant, Department Of "Technology Of Storage And Processing Of Agricultural Products", \\ Fergana Polytechnic Institute, Fergana, Uzbekistan
}

\title{
ABSTRACT
}

The article deals with agrotechnical measures and special measures related to the timing and depth of sowing, depending on the soil conditions of each region, each field, as well as the timely cultivation between rows.

\section{KEYWORDS}

Norm, Term, Soil, Cultivator, Plant Row.

\section{INTRODUCTION}

The Republic of Uzbekistan is the most northern region of cotton-producing countries in the world. The climate here is continental, with rainy days lasting until March and even the first ten days of April. Therefore, the best time for sowing is during the second decade of April and the fifth day of May. Seeds should be sown correctly and in a timely manner with sufficient moisture to produce a high-quality cotton crop. When exposed to inadequate soil, most of the soil decomposes and the rest grows poorly and sparingly. 


\section{THE MAIN PART}

When determining the sowing time, it is important to take into account that the cotton is a warm plant, with a temperature of $20-250$ for normal growth and development. Based on the results of many years of research and development experience of the research institutions, the sowing of seeds should be completed within the following timeframe:

1. April 5-15 in Tashkent and Ferghana regions.

2. April 1-15 in Syrdarya, Jizzakh, Namangan, Andijan and Bukhara regions.

3. In mountainous areas of the Andijan region and in Samarkand region April 520.

4. March 25 in the southern districts of the Surkhandarya region. Until April 10, April 1-15 in the Northern District.

5. In the southern regions of Kashkadarya from 25 March to 15 April, in the northern areas from 1 to 15 April.

6. It is recommended to plant in the Khorezm region and southern districts of the Karakalpak Autonomous Republic from April 10 to 25, and in the northern districts of the autonomous republic until April 15-30.

Seedless seeds are sown after 5-6 days in comparison with hairy seeds. Depending on the weather, these terms can be delayed for 23 days or backwards is possible. The timing and depth of the sowing should be determined according to the soil conditions of each farm and even each field.

In our experience in grassy-soil soils of the Fergana region, the seeds of cotton seeds S8290 and S6775, according to the soil condition, were planted to a depth of $3-4 \mathrm{~cm}$ with a daily average soil temperature of $10 \mathrm{~cm}$. When sowing seeds, it is necessary to take into account that the amount of residual fibre on the seeds should not exceed $0.8 \%$ in the medium-fibre types and $0.4 \%$ in the thin fibre varieties. The seeds may not fall evenly from the sowing apparatus and the sprouts may be sparse.

Providing fertilizers in most cotton fields is one of the most important tasks. According to the results of many years of research, from 7 to $10 \%$ of the annual fertilizer rate from cotton to weeding, nitrogen requires about $5-7 \%$ of phosphorus. When cotton is sprouted, the soil will not be able to absorb the nitrogen and phosphorus it contains. That is why nitrogen, phosphorus and potassium fertilizers, given at the same time as sowing, have significant benefits for the rapid development of cotton. These fertilizers have a positive effect on the plant's faster absorption of mobile nitrogen, phosphorus and potassium in the soil.

Based on the above scientific results, in our experience, we have $30-40 \mathrm{~kg}$ of urea per hectare and $40-50 \mathrm{~kg}$ of amorphous tractor cultivator per sow, with 6-8 rows per sowing row 10-12 cm deep. In addition, the timely cultivation of cotton fields is one of the most important factors for achieving high yields.

By increasing the inter-row cultivation of cotton, the activity of microorganisms in the soil will be improved, and the plant's micro-and macro-organisms will increase. As a result, the vitality of plant roots is improved through oxygen enrichment by air exchange in the soil. Rapid processing of young cotton plantations facilitates the development of young seedlings by providing porous soil and hot air. 
The American Journal of Agriculture and Boimedical Engineering

(ISSN - 2689-1018)

IMPACT FACTOR

Published: September 30, 2021| Pages: 26-29

Doi: https://doi.org/10.37547/tajabe/Volume03lssue09-05

2021: 5.554

OCLC - 1121105746

When working the rows, the sow is planted to a width of $60 \mathrm{~cm}$, taking into account the age of the sprout. If planted, appropriate soil mitigation and grazing facilities will be established. During the second and subsequent processing, the working bodies may be installed $3-4,5-6 \mathrm{~cm}$ deep, in both widths. It should be remembered that the number of cultivations is 6-7 times on light and sandy soils and 7-8 times on medium and heavy soils. $25-30 \mathrm{~cm}$ depth should be softened once.

If this method is not applied (ie not deeply cultivated) before sowing, the soil will be interrupted by the reduction of moisture content in the soil before further cultivation. After $7-10 \mathrm{~cm}$ of soil, an artificial wall will be formed. This should not be allowed.

\section{CONCLUSION}

From the experiments, it can be concluded that the fertilizer should be in proportion to the seeding rate and pay attention to the amount of residual fibres on the hairy seeds. Early cultivation allows the field to be well cleaned due to the loss of weeds during their early age.

\section{REFERENCES}

1. Teshayev F., Ubaydullayev M. (2019). Determining the optimal rate and duration of application of new defoliants in cotton in the context of the Fergana region. Agro-ilm. Tashkent. (4). p.16.

2. Teshayev F., Ubaydullayev M. (2020). Determining the effective norm of new defoliants in the conditions of lovesolonchakovix soil in the Fergana region at the discovery of boxes 50$60 \%$ of varieties of cotton S- 8290 and S-
6775. Actual problems of modern science. Russia. 5(114). p.62.

3. M.M. Ubaydullaev. The importance of sowing and handling of c-8290 and c6775 seeds in the conditions of the meadow soils of the Fergana area. India, 2020. pp.11.

4. Шодмонов, Х. М., Неьматова, Ф. Ж. К., \& Акрамов, Ш. Ш. У. (2020). Эффективность механизации технологических процессов уборки и первичной обработки лука; [Efficiency of the mechanization of technological processes of harvesting and primary processing of onion]. Universum: технические науки, (12-4 (81)). (in Russian). https://7universum.com/ru/tech/archiv e/item/11081.

5. Mirzayeva, M., Akramov, S., \& Abdukarimova, D. (2020). Biology Of Sugar Beet, As Well As The Scientific Basis For The Cultivation of Ecologically Pure Products. The American Journal of Agriculture and Biomedical Engineering, 2, 7-10.

6. Шодмонов, Х. М., \& Неьматова, Ф. Ж. К. (2020). К обоснованию условия и режима работы универсальных грейферных погрузчиков при погрузке хлопка-сырца в транспортные средства; [То justification of the conditions and operating mode of universal grapple loaders when loading raw cotton into vehicles]. Universum: технические науки, (11-2 (80)). (in Russian). https://7universum.com/ru/tech/archiv e/item/10902.

7. Ubaydullaeva, Sh.T., Ubaydullaev, M.M. (2021). Study of the effect of 
The American Journal of Agriculture and Boimedical Engineering (ISSN - 2689-1018)

Published: September 30, 2021| Pages: 26-29

Doi: https://doi.org/10.37547/tajabe/Volume03Issue09-05

OCLC - 1121105746

defoliants on cotton plants. Fergana, №10. pp-47-50.

8. Нейматова, Ф., \& Шодмонов, Х. М.

(2020). Влияние минеральных

удобрений на урожайность зерна сои; [The influence of mineral fertilizers on the yield of soybeans].

Актуальная наука, (1), 25-29. 